\title{
Effects of Cattle Manure Wood-Ash Compost on Some Chemical, Physical and Microbial Properties of Two Acid Tropical Soils
}

\author{
Blaise Pascal Bougnom $^{1 *}$, Aristide Molemb Nemete ${ }^{2}$, Guy Faustin Mbassa ${ }^{2}$, Pierre Effa Onomo ${ }^{2}$ and \\ Francois-Xavier Etoa ${ }^{1}$ \\ ${ }^{1}$ Department of Microbiology, Faculty of Science, \\ University of Yaoundé 1, P.O. Box 812 Yaounde, Cameroon \\ ${ }^{2}$ Department of Biochemistry, Faculty of Science, \\ University of Yaoundé 1, P.O. Box 812 Yaounde, Cameroon
}

\begin{abstract}
A field study was conducted to assess the potential of cattle manure wood-ash compost in order to improve soil fertility and productivity in two areas in the centre region of Cameroon distant of $200 \mathrm{~km}$. The farms were amended with four types of compost, C1 (100\% cattle manure compost), C2 (95\% cattle manure with 10\% wood ash admixture), C3 (90\% cattle manure compost and 10\% wood ash admixture), and C4 (85\% cattle manure compost and 15\% wood ash admixture). Soybean was the growing plant during the experiment which lasted three months. After the harvesting, physical, chemical, biological and plant parameters were evaluated. The compost significantly increased soil pH, Electrical conductivity, total organic carbon, total nitrogen, concentrations of $\mathrm{Ca}^{2+}, \mathrm{Mg}^{2+}, \mathrm{K}^{+}, \mathrm{Na}^{+}$, and total phosphorus. The composts also had a stimulatory effect on the total soil bacteria and fungi, cellulase and protease activities. Improvement soil physical, chemical and microbial parameters enhanced biomass production and yield. In summary, cattle manure wood-ash composts could be used for alleviating soil acidity and improve soil fertility of tropical acid soils. Future research is needed to address its sustainability in a long-term study.
\end{abstract}

Key Words: Compost, Cattle Manure, Wood-Ash, Tropical Acid Soils, Soil Fertility.

\section{INTRODUCTION}

Chemical fertilizers and big quantities of pesticides are generally used in intensive agriculture to increase yields, but the ecological consequences are significant. They include soil quality deterioration, environmental and water pollution, presence of pesticide residues in food, the emergence of new pathogens and pests more and more resistant to pesticides. This represents a serious threat to human health via direct or indirect exposure via the food chain [1]. In this context, new areas of research oriented in the use of natural fertilizers such as compost and manure are increasingly encouraged for their eco-compatibility. Acidic tropical soils cover more than $70 \%$ of the arable land in Cameroon [2]. These soils are characterized mainly by their low pH, their low organic matter $(\mathrm{OM})$ content, their deficiency in macronutrients $(\mathrm{Ca}, \mathrm{Mg}, \mathrm{N}, \mathrm{P}, \mathrm{K})$, and micronutrients, their toxicity in $\mathrm{Al}$, $\mathrm{Mn}$ and Fe [3]. Several agricultural methods have been suggested to tackle the challenging problem of poor fertility of acidic tropical soils. The most recommended is liming which is defined as an application of ground carbonates of calcium and/or magnesium, hydroxides, and oxides to increase soil pH, thereby altering its chemical, physical, and biological properties [4]. Large amounts of lime are generally required to improve plant growth, but unfortunately for many farmers in the tropics, the high cost of lime prevents its use [5]. Organic waste has been successfully implemented so far in addressing the problem of soil acidity and represents a suitable alternative to the use of lime [6]. Composting is the controlled decomposition and transformation of organic matter by a succession of microbial communities under aerobic conditions to produce a humus like material [7]. 
International Journal of Advances in Scientific Research and Engineering (ijasre), Vol 6 (4), April -2020

Composting is widespread in high income countries and need to be vulgarised in developing countries such as Cameroon. The nature of the organic material used, its source, and the conditions under which composting was made determine the quality of the compost. The main purpose of composting is to provide a stable and highly nutrient-rich product that is easily usable by the plant [8]. The use of compost in agriculture allows to maintain long-term biological activity of amended soils and delivers nutrients that are slowly released for plant needs [8-9]; it also helps to replace and maintain long-term soil fertility by increasing soil biological activity and providing nutrients that are released slowly to meet plant needs [10].

Animal manure is used for soil fertilisation in sub-Saharan Africa and provides soils with macro and micronutrients, with cattle manure being the most important. Cattle manure provides high content of nutrients for plant growth and can be used as alternative to mineral fertilizers [11]. Wood ash is a by-product of wood. After the wood is burned, several nutrients, trace elements, heavy metals are kept in the ash. This ash is a considerable source of $\mathrm{P}, \mathrm{K}, \mathrm{Mg}, \mathrm{Ca}$, and lime. Wood ash can therefore be used as a supplement to organic fertilizers [12-13]. Wood ash admixture to compost has the distinction of having a higher liming potential and can thus reduce the amount of compost required to increase $\mathrm{pH}$ to appropriate levels in acidic tropical soils. Wood ash admixture to compost improves compost quality and represents good attribute by improving physical and chemical properties of the soil [14]. The use of composts made from livestock waste in agriculture has been recognised to improve soil fertility and productivity [15-16].

In this paper, we assess the physical, chemical and microbial impact of the use of locally produced composts from cattle manure and wood ash on two acidic soils in Cameroon.

\section{MATERIAL AND METHODS}

\subsection{Composts origin}

The composts used were produced from cattle manure and wood ash in proportion of $0,5,10$ and $15 \%$ wood ash/ cattle manure (w/w), respectively, after 4 months composting [17]. They were named C1, C2, C3 and C4. Cattle manure was obtained from the municipal slaughterhouse of the town of Yaounde; and wood ash (bottom ash) was collected from an incineration wood plant. The physical and chemical characteristics of the composts are given in Table 1.

Table 1. Physical and chemical characteristics of the composts and the soils.

\begin{tabular}{lcccccc}
\hline \multirow{2}{*}{ Paramètres } & \multicolumn{2}{c}{ Composts } & \multicolumn{3}{c}{ Soils } \\
\cline { 2 - 7 } & $\mathrm{C} 1$ & $\mathrm{C} 2$ & $\mathrm{C} 3$ & $\mathrm{C} 4$ & Bok & Nkol \\
\hline $\mathrm{pH}$ & 7.01 & 7.89 & 8.58 & 8.72 & 5.1 & 4.6 \\
$\mathrm{CE}\left(\mu \mathrm{S} . \mathrm{cm}^{-1}\right)$ & 2.01 & 2.05 & 2.09 & 2.19 & 0.5 & 0.3 \\
Corg $(\%)$ & 9.32 & 8.37 & 7.44 & 5.58 & 0.5 & 1.3 \\
Total N $(\%)$ & 0.62 & 0.57 & 0.52 & 0.45 & 0.1 & 0.1 \\
Total P $(\mathrm{mg} \cdot \mathrm{kg}-1)$ & 350 & 300 & 600 & 500 & 2.4 & 1 \\
$\mathrm{C} / \mathrm{N}$ & 14.9 & 14.6 & 14,31 & 12.3 & 11.1 & 11.5 \\
$\mathrm{Mg}^{2+}\left(\mathrm{mg} \cdot \mathrm{kg}^{-1}\right)$ & 75 & 80 & 90 & 205 & 0.3 & 0.4 \\
$\mathrm{Ca}^{2+}\left(\mathrm{mg} \cdot \mathrm{kg}^{-1}\right)$ & 0.39 & 0.22 & 0.25 & 0.45 & 0.4 & 0.7 \\
$\mathrm{~K}^{+}\left(\mathrm{mg} \cdot \mathrm{kg}^{-1}\right)$ & 0 & 60 & 66 & 82 & 0.05 & 0.06 \\
$\mathrm{Na}^{+}\left(\mathrm{mg} \cdot \mathrm{kg}^{-1}\right)$ & 0 & 6.5 & 6.5 & 6.5 & 0.03 & 0.03 \\
\hline
\end{tabular}

Dissimilar letters in a column indicate statistically significant differences among the different treatments (n=3; Tukey B-test).

\subsection{Study sites and experimental design}

The field trials were conducted in two localities in the Centre Region of Cameroon, in the localities of Nkolbisson (Nkol) (3-51'N 11-30'E), and Bokito (Bok) (4-34'N, 11-7'E), distant of $120 \mathrm{~km}$. 
International Journal of Advances in Scientific Research and Engineering (ijasre), Vol 6 (4), April -2020

The areas are located in the forest humid zone, Nkol is classified as Oxisol and Bok as Ultisol. The experimental design was a randomized block design $\left(6 \mathrm{~m}^{2}\right.$ per plot separated by $\left.1 \mathrm{~m}\right)$ with 3 replicates. The distance between block and plants were $60 \mathrm{~cm}$ and $50 \mathrm{~cm}$, respectively. In each farm, the treatment consisted of untreated plots (control) and treated plots with composts $(\mathrm{C} 1$, C2, C3, and C4). A week prior planting, $100 \mathrm{~g}$ of composts were mixed with plots, at the seeding place. Three seeds of soybean (Glycine max L.) were sown on the different plots for three months growing period. After the growing period, the plants were harvested, and the replicates of soil per treatment sampled. A part was stored at $4^{\circ} \mathrm{C}$ for biological analyses, the other part was airdried, sieved $(<2 \mathrm{~mm})$ and used for physical and chemical analysis.

\subsection{Physical, chemical and biological analysis}

$\mathrm{pH}$ and EC (electrical conductivity) were measured in a 1:2.5 (soil: demineralized water) ratio using a glass electrode. Organic $\mathrm{C}$ (Corg) and total $\mathrm{N}$ were determined by dry combustion at $950^{\circ} \mathrm{C}$ in a $\mathrm{C}, \mathrm{N}, \mathrm{H}$ analyser. Nutrients $(\mathrm{P}, \mathrm{K}, \mathrm{Ca}, \mathrm{Mg}$, and $\mathrm{Na}$ ) contents that were determined after wet digestion by inductively coupled plasma atomic emission spectroscopy (ICP-AES). The biological tests consisted in the determination of plant yield, the total aerobic mesophilic bacteria, and total fungi in soils that were isolated and enumerated on Luria broth agar (LBA) and Potato dextrose agar (PDA) respectively, and results expressed as colony forming units (CFU) per gram dry soil. The activity levels of enzymes cellulase and protease were measured as described [18].

\subsection{Statistical analyses}

The data obtained were subjected to a two-way analysis of variance (ANOVA) followed by a Tukey's B-test at $5 \%$ level. The data were analysed using SPSS Software Package 16.

\section{RESULTS AND DISCUSSION}

The values of $\mathrm{pH}$, electrical conductivity, total carbon, total nitrogen and $\mathrm{C} / \mathrm{N}$ ratio of the different amended soils after the harvest are reported in Table 2.

Table 2. pH, EC, Org C, total $\mathrm{N}$ and $\mathrm{C} / \mathrm{N}$ ratio in the different soils treated or not with composts (mean $\pm \mathrm{SD}$ ).

\begin{tabular}{llccccc}
\hline \multicolumn{7}{c}{ Treatments } \\
\hline Parameters & Soil & Control & C1 & C2 & C3 & C4 \\
\hline $\mathrm{pH}$ & Bok & $5.1 \pm 0.2^{\mathrm{a}}$ & $6.03 \pm 0.44^{\mathrm{b}}$ & $6.39 \pm 0.25^{\mathrm{bc}}$ & $6.50 \pm 0.23^{\mathrm{bc}}$ & $6.71 \pm 0.29^{\mathrm{c}}$ \\
& Nkol & $4.5 \pm 0.2^{\mathrm{a}}$ & $6.55 \pm 0.29^{\mathrm{b}}$ & $7.10 \pm 0.48^{\mathrm{bc}}$ & $6.86 \pm 0.21^{\mathrm{b}}$ & $7.65 \pm 0.51^{\mathrm{c}}$ \\
$\mathrm{EC}(\mu \mathrm{s} / \mathrm{cm})$ & Bok & $100 \pm 10^{\mathrm{a}}$ & $110.7 \pm 32.9^{\mathrm{a}}$ & $115.5 \pm 51.5^{\mathrm{a}}$ & $137.5 \pm 61.4^{\mathrm{a}}$ & $138 \pm 58.8^{\mathrm{a}}$ \\
& Nkol & $40 \pm 2^{\mathrm{a}}$ & $90 \pm 39.1^{\mathrm{b}}$ & $107.3 \pm 46.5^{\mathrm{b}}$ & $110 \pm 47.6^{\mathrm{b}}$ & $120,7 \pm 53.1^{\mathrm{b}}$ \\
$\mathrm{C}_{\text {org }}(\%)$ & Bok & $0.6 \pm 0.01^{\mathrm{a}}$ & $11.5 \pm 0,10^{\mathrm{c}}$ & $12.4 \pm 0.10^{\mathrm{d}}$ & $12.3 \pm 0.10^{\mathrm{d}}$ & $11.1 \pm 0.10^{\mathrm{b}}$ \\
& Nkol & $1.5 \pm 0.01^{\mathrm{a}}$ & $12.8 \pm 0.05^{\mathrm{c}}$ & $13 \pm 0.10^{\mathrm{de}}$ & $12.8 \pm 0.10^{\mathrm{cd}}$ & $12.6 \pm 0.10^{\mathrm{b}}$ \\
$\mathrm{N}_{\mathrm{t}}(\%)$ & Bok & $0.02 \pm 0.00^{\mathrm{a}}$ & $0.8 \pm 0.01^{\mathrm{c}}$ & $0.80 \pm 0.00^{\mathrm{d}}$ & $0.84 \pm 0.01^{\mathrm{d}}$ & $0.71 \pm 0.01^{\mathrm{b}}$ \\
& Nkol & $0.1 \pm 0.01^{\mathrm{a}}$ & $0.98 \pm 0.00^{\mathrm{d}}$ & $0.98 \pm 0.01^{\mathrm{d}}$ & $0.94 \pm 0.01^{\mathrm{c}}$ & $0.92 \pm 0.01^{\mathrm{b}}$ \\
$\mathrm{C} / \mathrm{N}$ & Bok & $30 \pm 0.3^{\mathrm{d}}$ & $14.4 \pm 0.05^{\mathrm{a}}$ & $15.5 \pm 0.15^{\mathrm{a}}$ & $14.7 \pm 0.23^{\mathrm{b}}$ & $16.5 \pm 0.10^{\mathrm{c}}$ \\
& Nkol & $15 \pm 0.20^{\mathrm{a}}$ & $13.00 \pm 0.10^{\mathrm{b}}$ & $13.3 \pm 0.05^{\mathrm{c}}$ & $13.6 \pm 0.11^{\mathrm{d}}$ & $13.7 \pm 0.15^{\mathrm{d}}$
\end{tabular}

Dissimilar letters in a column indicate statistically significant differences among the different treatments (n=3; Tukey B-test).

In both soils, soil $\mathrm{pH}$ significantly increased in amended soils, with highest value obtained under $\mathrm{C} 4$ treatment. Soil $\mathrm{pH}$ was 0.93 to 1.61 , and 2.05 to 3.15 unit higher in Bokito and Nkolbisson compared to the control, respectively. Electrical conductivity increased following compost amendment, but the difference was significant only in Nkolbisson when compared to the control. Total organic carbon significantly increased in both soils following composts application. The highest values were 
obtained under C2 and C3 amendments in both soils. Following organic carbon increase, total nitrogen also increased in amended soils, with better results under C3 and C2 in Bokito and Nkolbisson, respectively. the $\mathrm{C} / \mathrm{N}$ ratio ranged from 13 to 16 in amended soils and was lower much than the control in both soils.

The $\mathrm{pH}$ of the composts was higher than that of the soils. Therefore, the increase in soil $\mathrm{pH}$ following addition of composts in both soils was not a surprise. In organic amended soils, there is a flow of protons from the soil to the organic matter sites, which will consequently increase the $\mathrm{pH}$ of the soil. Additionally, organic materials are rich in humic substances and have both liming value and proton consumption capacity [19-20. Previous studies have reported significant increase of soil organic carbon following compost application [21]. Our study is in accordance with these previous findings. The increase of soil in organic carbon is consequent of to the increase of soil organic matter (SOM). SOM is composed of organic carbon and the $\mathrm{N}$ in soil in organic form [22]. Increase of organic carbon will improve high water and nutrient holding capacity, and thus physical, chemical and biological properties of the amended soils [23]. Over $90 \%$ of total $\mathrm{N}$ in compost is come from the organic $\mathrm{N}$ pool. Thus, an increase of the soil total $\mathrm{N}$ was expected following an increase of soil total organic $\mathrm{C}$. It is reported that a $\mathrm{C} / \mathrm{N}$ ratio $<12$ could lead to $\mathrm{N}$ leaching, while a $\mathrm{C} / \mathrm{N}$ ratio $>20$ could cause $\mathrm{N}$ immobilisation [24]. For use in agriculture, a $\mathrm{C} / \mathrm{N}$ ratio $<20$ is required for optimal plant availability [25]. The $\mathrm{C} / \mathrm{N}$ ratios of the amended soils ranged from 13 to 16.5 , which is a range found in fertile soils [26]. Our composts do not neither lead to $\mathrm{N}$ leaching nor immobilisation.

Concentrations of $\mathrm{Ca}^{2+}, \mathrm{Mg}^{2+}, \mathrm{K}^{+}, \mathrm{Na}^{+}$, and total phosphorus are reported in table 3 .

Table 3. Concentration of exchangeable $\mathrm{Ca}^{2+}, \mathrm{Mg}^{2+}, \mathrm{K}^{+}$, and total $\mathrm{P}$ in the different soils treated or not with composts (mean $\pm \mathrm{SD}$ ).

\begin{tabular}{|c|c|c|c|c|c|c|}
\hline \multicolumn{7}{|c|}{ Treatments } \\
\hline Parameters & Soil & Control & $\mathrm{C1}$ & $\mathrm{C2}$ & C3 & $\mathrm{C4}$ \\
\hline \multirow[t]{2}{*}{$\mathrm{Ca}^{2+}\left(\mathrm{mg} \cdot \mathrm{kg}^{-1}\right)$} & Bok & $0.04 \pm 0.02^{\mathrm{a}}$ & $12 \pm 2.60^{b}$ & $12 \pm 1.60^{b}$ & $14 \pm 2.30^{c}$ & $14.4 \pm 0.15^{\mathrm{d}}$ \\
\hline & Nkol & $0.7 \pm 0.01^{\mathrm{a}}$ & $16 \pm 0.90^{\mathrm{b}}$ & $15 \pm 0.60^{\mathrm{b}}$ & $14 \pm 0.70^{b}$ & $16 \pm 0.80^{c}$ \\
\hline \multirow[t]{2}{*}{$\mathrm{Mg}^{2+}\left(\mathrm{mg} \cdot \mathrm{kg}^{-1}\right)$} & Bok & $0.4 \pm 0.01^{\mathrm{a}}$ & $2 \pm 0.30^{\mathrm{b}}$ & $2 \pm 0.20^{\mathrm{b}}$ & $4 \pm 0.40^{c}$ & $4 \pm 0.30^{\mathrm{c}}$ \\
\hline & Nkol & $0.3 \pm 0.01^{\mathrm{a}}$ & $2 \pm 0.10^{\mathrm{b}}$ & $2 \pm 0.10^{\mathrm{b}}$ & $2 \pm 0.15^{\mathrm{b}}$ & $2 \pm 0.10^{b}$ \\
\hline \multirow[t]{2}{*}{$\mathrm{K}^{+}\left(\mathrm{mg} \cdot \mathrm{kg}^{-1}\right)$} & Bok & $0.06 \pm 0.01^{\mathrm{a}}$ & $0.47 \pm 0.10^{\mathrm{b}}$ & $0.68 \pm 0.16^{\mathrm{b}}$ & $1.15 \pm 0.35^{\mathrm{c}}$ & $0.72 \pm 0.14^{b}$ \\
\hline & Nkol & $0.05 \pm 0.01^{\mathrm{a}}$ & $0.34 \pm 0.47^{\mathrm{b}}$ & $0.39 \pm 0.10^{\mathrm{b}}$ & $0.61 \pm 0.05^{\mathrm{b}}$ & $0.53 \pm 0.10^{b}$ \\
\hline \multirow[t]{2}{*}{$\mathrm{Na}^{+}\left(\mathrm{mg} \cdot \mathrm{kg}^{-1}\right)$} & Bok & $0.04 \pm 0.02^{\mathrm{a}}$ & $0.43 \pm 0.08^{\mathrm{b}}$ & $0.95 \pm 0.40^{\mathrm{bc}}$ & $1.10 \pm 0.45^{\mathrm{c}}$ & $2.26 \pm 0.25^{\mathrm{d}}$ \\
\hline & Nkol & $0.03 \pm 0.01^{\mathrm{a}}$ & $0.43 \pm 0.05^{\mathrm{b}}$ & $0.63 \pm 0.15^{\mathrm{b}}$ & $0.61 \pm 0.05^{\mathrm{b}}$ & $0.60 \pm 0.10^{\mathrm{b}}$ \\
\hline \multirow[t]{2}{*}{ Total P (mg. $\left.\mathrm{kg}^{-1}\right)$} & Bok & $2.1 \pm 0.10^{\mathrm{a}}$ & $10.0 \pm 4.36^{\mathrm{bc}}$ & $10.0 \pm 4.58^{\mathrm{bc}}$ & $15.0 \pm 0.00^{\mathrm{c}}$ & $7.53 \pm 3.32^{b}$ \\
\hline & Nkol & $2 \pm 0.20^{\mathrm{a}}$ & $11.7 \pm 1.70^{\mathrm{b}}$ & $16.7 \pm 4.40^{\mathrm{bc}}$ & $18.5 \pm 2.50^{\mathrm{c}}$ & $16.7 \pm 0.50^{\mathrm{bc}}$ \\
\hline
\end{tabular}

Dissimilar letters in a column indicate statistically significant differences among the different treatments ( $\mathrm{n}=3$; Tukey B-test).

Concentrations of $\mathrm{Ca}^{2+}, \mathrm{Mg}^{2+}, \mathrm{K}^{+}$and $\mathrm{Na}^{+}$significantly increased upon compost application in both soils. The higher increase was generally observed in soil amended by C4. Following macro and micronutrients increase, total phosphorus also significantly increased upon compost application. Soils under C3 having the greater values in Bokito and Nkolbisson, respectively.

The increase of extractable cations $(\mathrm{Ca}, \mathrm{K}, \mathrm{Mg}$ and $\mathrm{Na}$ ) following compost amendments in tropical soils has been previously reported [27]. Acid tropical soils are generally depleted in nutrients which high rate of mineralisation. The leaching potential of nutrients from soil depends on its buffering capacity which relies on calcium availability. When calcium is depleted, $\mathrm{Al}$ takes over the buffering role with $\mathrm{Al}$ toxicity as the consequence [28]. Al toxicity is one of the main growth-limiting factors for crop production in tropical acid soils [29-30]. The increase of extractable $\mathrm{Ca}$ is therefore a very good attribute since the soil potential for leaching of soil nutrients depends on its quantity and availability [31]. The greater performances of C3 and C4 could be related to the fact that they have greater amount of wood ash which is reach in $\mathrm{Ca}^{2+}$. Electrical conductivity of the amended soils increased following the increase in salt content. C3 and C4 having the higher values. However, even though the values of 
International Journal of Advances in Scientific Research and Engineering (ijasre), Vol 6 (4), April -2020

EC were compatible to agricultural soil EC levels which range from 0 to $4 \mathrm{dSm}^{-1}$ [32], we should observe that greater amount of wood ash in compost led to greater values in EC. Thus, the use of wood ash in tropical agriculture should be handle with care. It is reported that organic wastes with a $\mathrm{P}$ content of more than $0.3 \%$ lead to a net $\mathrm{P}$ mineralization and adsorption of the released $\mathrm{P}$ [33]. Thus, $\mathrm{P}$ increase following compost application was expected since all the composts had a P content over $0.3 \%$. An increase of $\mathrm{P}$ concentration is correlated with a decrease in aluminium toxicity which means an improvement of soil fertility and plant growth $[19,34,35]$.

Compost amendment had a stimulatory effect on the total soil bacteria and fungi which significantly increased in both soils (Table 4). Greater stimulatory effect on total mesophilic bacteria was observed upon C2 and C3 application in both soils. Increase in total soil fungi was not significantly different in amended soils. Following total bacteria and fungi increase in amended soils, cellulase and protease activities also increased. Highest cellulase activity was observed upon C3 amendment in Bokito, and C2 and C3 in Nkolbisson, respectively. highest proteases activity was observed upon C2 and C3 in Bokito, and C1 in Nkolbisson, respectively.

Table 4. Total bacteria, total fungi, cellulase and protease activity in the different soils treated or not with composts (mean \pm SD).

\begin{tabular}{|c|c|c|c|c|c|c|}
\hline \multicolumn{7}{|c|}{ Treatments } \\
\hline Parameters & Soil & Control & C1 & $\mathrm{C2}$ & C3 & C4 \\
\hline Total bacteria & Bok & $4.09 \pm 0.05^{\mathrm{a}}$ & $6.41 \pm 0.02^{\text {cd }}$ & $6.44 \pm 0.00^{\mathrm{d}}$ & $6.38 \pm 0.08^{\text {cd }}$ & $6.33 \pm 0.02^{\mathrm{bc}}$ \\
\hline & Nkol & $4.02 \pm 0.07^{\mathrm{a}}$ & $6.30 \pm 0.00^{\mathrm{b}}$ & $6.36 \pm 0.02^{\mathrm{bcd}}$ & $6.40 \pm 0.06^{\mathrm{cd}}$ & $6.37 \pm 0.05^{\mathrm{bc}}$ \\
\hline Total fungi ( $\log$ & Bok & $3.22 \pm 0.03^{\mathrm{a}}$ & $4.97 \pm 0.01^{\mathrm{b}}$ & $4.97 \pm 0.01^{\mathrm{b}}$ & $4.98 \pm 0.01^{\mathrm{b}}$ & $4.97 \pm 0.01^{\mathrm{b}}$ \\
\hline & Nkol & $3.34 \pm 0.04^{\mathrm{a}}$ & $4.96 \pm 0.01^{b}$ & $4.97 \pm 0.01^{\mathrm{b}}$ & $4.96 \pm 0.01^{\mathrm{b}}$ & $4.96 \pm 0.00^{\mathrm{b}}$ \\
\hline Cellulase activity & Bok & $2.04 \pm 0.11^{\mathrm{a}}$ & $4.55 \pm 0.11^{\mathrm{b}}$ & $4.50 \pm 0.11^{\mathrm{b}}$ & $5.50 \pm 0.11^{\mathrm{c}}$ & $4.60 \pm 0.11^{\mathrm{b}}$ \\
\hline $\operatorname{Pr}$ & $\begin{array}{l}\text { Nkol } \\
\text { Bok }\end{array}$ & $\begin{array}{l}2.04 \pm 0.01^{\mathrm{a}} \\
0.16+0.01^{\mathrm{a}}\end{array}$ & $\begin{array}{l}6.92 \pm 0.01^{\mathrm{d}} \\
0.31+0.01^{\mathrm{c}}\end{array}$ & $\begin{array}{l}5.90 \pm 0.01^{\mathrm{c}} \\
0.36+0.01^{\mathrm{d}}\end{array}$ & $5.88 \pm 0.01^{\mathrm{c}}$ & $\begin{array}{l}4.05 \pm 0.01^{b} \\
025+0.01^{b}\end{array}$ \\
\hline & Nkol & $0.12 \pm 0.01^{\mathrm{a}}$ & $0.85 \pm 0.01^{\mathrm{d}}$ & $0.46 \pm 0.01^{\mathrm{c}}$ & $0.41 \pm 0.01^{\mathrm{c}}$ & $0.35 \pm 0.01^{b}$ \\
\hline
\end{tabular}

Dissimilar letters in a column indicate statistically significant differences among the different treatments ( $\mathrm{n}=3$; Tukey B-test).

Organic farming is reported to enhance total microbial biomass and activity in agricultural soils, with organic matter acting as a source of energy and carbon which stimulates the growth of microorganisms in soils [36, 37]. The increase in bacterial and fungal biomass in the amended soils is the result of the improved soil chemical and physical parameters, following organic matter input. Enhancement of total organic carbon, nitrogen and nutrients improves both microbial metabolism and biomass over several years $[9,38]$. The soil microbial biomass increase could be mainly due to the stimulation of the soil indigenous community rather than the transfer of microorganisms from cattle manure to the soil. It has been reported that indigenous microbiome in cattle manure has limited influence on soil microorganisms as most of the bacterial species in cattle manure are less competitive in the soil environment $[39,40]$. The relatively stable fungal biomass observed in all amended soils could be explained by the fact that fungi when compared to bacteria and actinomycetes are more resistant to changes in the nutrient contents of soil and have slow biomass turnover rate [41]. Enzymes are considered as potential indicators of soil quality and are closely related to the activity and abundance of microorganisms $[42,43]$. Soil enzymes are mainly of microbial origin and respond quickly to any change in soil management $[44,45]$. It has been reported that $\mathrm{C}$ source addition to soil increases soil $\mathrm{pH}$ and stimulate both microbial activity and community in short term [37,46]. The increase in cellulase and protease activities in the treated soils is consequent to the increase in fungal and bacterial metabolism and biomass. Addition of high dose of wood ash has been reported to inhibit microbial activity [47]. Thus, the lower cellulase activity under C4 amendment compared to other treatments could be explained by the higher amount of wood ash in this compost. Our results indicate that the application of cattle manure ash compost can compensate for loss of organic matter and soil acidity of tropical soil, and thus could improve physical, chemical and biological properties of tropical acid soils indirectly if not directly. 
International Journal of Advances in Scientific Research and Engineering (ijasre), Vol 6 (4), April -2020

The values of the leaf surface, stem size, diameter collar, number of soybean leaves, and average seed mass are reported in Table 5. In Bokito, the plant parameters under C4 were not significantly different to the control. In Nkolbisson, the plant parameters were greater in the amended pots. Improvement of soil physical, chemical and microbial parameters was translated into higher yields in both soils. Average seed mass was significantly higher upon compost amendment in Bokito; the better yields were observed under $\mathrm{C} 1$ and $\mathrm{C} 2$ amendment. Average seed mass was significantly higher upon C1 and C2 application in Nkolbisson; the higher value was obtained under C2 application.

Table 5. Stem size, leaf surface, number of leaves, diameter collar and average seed mass in the different soils treated or not with composts (mean \pm SD).

\begin{tabular}{lcccccc}
\hline \multicolumn{7}{c}{ Treatments } \\
Parameters & Soil & Control & C1 & C2 & C3 & C4 \\
\hline Stem size & Bok & $36.8 \pm 1.34^{\mathrm{ab}}$ & $42.6 \pm 2.76^{\mathrm{b}}$ & $36.9 \pm 6.00^{\mathrm{ab}}$ & $40.5 \pm 4.9^{\mathrm{b}}$ & $27 \pm 8.54^{\mathrm{a}}$ \\
& Nkol & $25.3 \pm 2.30^{\mathrm{a}}$ & $50.3 \pm 7.52^{\mathrm{b}}$ & $50.3 \pm 7.23^{\mathrm{b}}$ & $51 \pm 14.4^{\mathrm{b}}$ & $49.2 \pm 3.81^{\mathrm{b}}$ \\
Leaf surface & Bok & $27.6 \pm 1.84^{\mathrm{a}}$ & $47.9 \pm 5.69^{\mathrm{b}}$ & $43.7 \pm 1.44^{\mathrm{b}}$ & $48 \pm 17.7^{\mathrm{b}}$ & $34.7 \pm 3.64^{\mathrm{ab}}$ \\
& Nkol & $10 \pm 0.78^{\mathrm{a}}$ & $56.7 \pm 2.17^{\mathrm{b}}$ & $54.4 \pm 8.09^{\mathrm{b}}$ & $56.3 \pm 7.77^{\mathrm{b}}$ & $54 \pm 9.41^{\mathrm{b}}$ \\
Number of leaves & Bok & $20 \pm 3.90^{\mathrm{a}}$ & $44.3 \pm 20.9^{\mathrm{ab}}$ & $41 \pm 9.84^{\mathrm{a}}$ & $67 \pm 5.65^{\mathrm{b}}$ & $23.3 \pm 8.50^{\mathrm{a}}$ \\
& Nkol & $9.67 \pm 1.52^{\mathrm{a}}$ & $40.7 \pm 6.65^{\mathrm{b}}$ & $38.3 \pm 3.78^{\mathrm{b}}$ & $38.3 \pm 3.78^{\mathrm{b}}$ & $40.3 \pm 12.8^{\mathrm{b}}$ \\
Diameter collar & Bok & $0.91 \pm 0.08^{\mathrm{ab}}$ & $1.12 \pm 0.17^{\mathrm{ab}}$ & $0.98 \pm 0.18^{\mathrm{ab}}$ & $1.25 \pm 0.21^{\mathrm{b}}$ & $0.80 \pm 0.27^{\mathrm{a}}$ \\
& Nkol & $0.45 \pm 0.05^{\mathrm{a}}$ & $1.28 \pm 0.18^{\mathrm{b}}$ & $1.25 \pm 0.12^{\mathrm{b}}$ & $1.38 \pm 0.29^{\mathrm{b}}$ & $1.22 \pm 0.18^{\mathrm{b}}$ \\
average seed mass $(\mathrm{g})$ & Bok & $1.5 \pm 0.01^{\mathrm{a}}$ & $7.18 \pm 0.09^{\mathrm{c}}$ & $8.35 \pm 0.17^{\mathrm{d}}$ & $4.52 \pm 0.88^{\mathrm{b}}$ & $3.37 \pm 0.62^{\mathrm{b}}$ \\
& Nkol & $2.5 \pm 0.02^{\mathrm{a}}$ & $6.2 \pm 0.02^{\mathrm{b}}$ & $7.5 \pm 0.03^{\mathrm{c}}$ & $2.2 \pm 0.04^{\mathrm{a}}$ & $2.3 \pm 0.02^{\mathrm{a}}$
\end{tabular}

Dissimilar letters in a column indicate statistically significant differences among the different treatments (n=3; Tukey B-test).

The improvement of soil parameters is associated with soil health improvement and productivity [23, 48]. Soil physical, chemical and biological parameters improvement resulted in more favourable growing conditions and provided nutrients necessary for the plant growth. This could explain greater plant parameters and yield in amended soils. However, the lower performances under C3 and C4 amendment suggest a kind of toxicity of wood ash to the growing plant. Wood ash for agriculture in the tropics should be used in acceptable proportions to avoid soil and plant toxicity.

\section{CONCLUSION}

The researcher successfully investigated the potential of cattle manure wood-ash compost in term of alleviating soil acidity and fertility of tropical acid soils. Our results showed that the composts improve soil chemical physical and microbial parameters. Soil pH, macronutrients content, bacterial and fungal biomass improved upon composts addition. Wood ash additive to compost allowed better performances. The compost did not show critical toxicity to the growing and the plant yield improved with cattle manure compost having up to $10 \%$ wood ash. Cattle manure wood-ash compost represent a suitable alternative to chemical fertilizers for resource poor farmers in the tropics and its sustainability should be tested in a long-term field study.

\section{REFERENCES}

[1] Bougnom BP, Knapp BA, Etoa FX, Insam H., 2011. Possible use of wood ash and compost for improving acid tropical soils. In: Insam H, Knapp BA (eds) Recycling of biomass ashes. Springer,Berlin. pp 87-103.

[2] Bindzi Tsala J., 1987. Les sols rouges du Cameroun. 8e réunion du souscomité ouest et centre Africain de correlation des sols pour la mise en valeur des terres. MINREST-FAO, Yaoundé, Cameroun. 
International Journal of Advances in Scientific Research and Engineering (ijasre), Vol 6 (4), April -2020

[3] Kochian LV, Hoekenga OA, Pineros MA., 2004. How do crop plants tolerate acid soils? mechanisms of aluminum tolerance and phosphorous efficiency. Annu Rev Plant Biol. 55 (459): 493

[4] Edmeades DC, Ridley AM., 2003. Using lime to ameliorate topsoil and subsoil acidity. In: Rengel, Z. (Ed.), Handbook of Soil Acidity. Marcel Dekker, Inc., New York, Basel. pp. 297-336.

[5] Noble AD, Zenneck I, Randall PJ., 1996. Leaf litter ash alkalinity and neutralisation of soil acidity. Plant Soil. 179, $293-302$.

[6] Hue NV., 1992. Correcting soil acidity of a highly weathered Ultisol with chicken manure and sewage sludge. Commun. Soil Sci. Plant Anal. 23, 241-264.

[7] Cerda A, Artola A, Font X, Barrena R, Gea T, Sánchez A., 2017. Composting of food wastes: status and challenges. Bioresour. Technol. 248, 57-67.

[8] Gobat JM, Aragno M, Mattey W., 2003. Le sol vivant, 2e édition revue et complétée. Presses Polytechniques et Universitaires Romandes. p. 319-319. In French.

[9] Ros, M., Klammer, S., Knapp, B., Aichberger, K., Insam, H., 2006. Long-term effects of compost amendment of soil on functional and structural diversity and microbial activity. Soil Use Manage. 22, 209-218.

[10] Bougnom BP, Knapp BA, Etoa FX, Elhottova’ D, Nemcova' A, Insam H., 2010. Designer composts for ameliorating acid tropical soils: effects on the soil microbiota. Appl Soil Ecol. 45:319-324.

[11] Sharpley A N, Smith SJ., 1995. Nitrogen and phosphorus forms in soils receiving manure. Soil Science, 159, $253-258$.

[12] Naylor LM, Schmidt E. 1989, Paper mill wood ash as a fertilizer and liming material: field trials. Tappi J. 72 (6), $199-206$.

[13] Bougnom BP, Insam H., 2009. Ash additives to compost affect soil microbial communities and apple seedling growth. Die Bodenkultur 60, 5-15.

[14] Bougnom BP, Mair J, Etoa FX, Insam H., 2009. Composts with wood ash addition: a risk or a chance for ameliorating acid tropical soils? Geoderma 153, 402-407.

[15] Tilman D, Cassman KG, Matson PA, Naylor R, Polasky S., 2002. Agricultural sustainability and intensive production practices. Nature 418, 671-677.

[16] Kravchenko AN, Snapp SS, Robertson GP., 2017. Field-scale experiments reveal persistent yield gaps in low-input and organic cropping systems. Proc. Natl. Acad. Sci. U.S.A. 114, 926-931.

[17] Bougnom BP, Dieudonne O., Sontsa-Donhoung A. M., 2020. Evaluation of wood ash as additive for cow manure composting. Int. Ann. Sci. 9:100-110.

[18] Tabatabai MA., 1994. Soil enzymes. In: Weaver RW., Angle JS., Bottomley P.S.(Eds.), Methods of

Soil Analysis, Part 2. Microbiological and Biochemical Properties. Soil Science Society of America, Madison, Wisconsin, $\mathrm{p} 775.833$.

[19] Haynes RJ, Mokolobate MS., 2001. Amelioration of Al toxicity and P deficiency in acid soils by additions of organic residues: a critical review of the phenomenon and the mechanisms involved. Nutr. Cycl. Agroecosyst. 59, 47-63.

[20] Wong MTF, Nortcliff S, Swift RS., 1998. Method for determining the acid ameliorating capacity of plant residue compost, urban waste compost, farmyard manure and peat applied to tropical soils. Commun. Soil Sci. Plant Anal. 29, $2927-2937$.

[21] Rizzo PF, DellaTorre V, Riera NI, Crespo D, Barrena R, Sanchez A., 2015. Co-composting of poultry manure with other agricultural wastes: process performance and compost horticultural use. Journal of Material Cycles and Waste Management.

$17: 42-50$.

[22] Batjes NH., 1996. Total carbon and nitrogen in soils of the world. Eur. J. Soil Sci. 47, 151-163.

[23] Arriagada C, Almonacid L, Cornejo P, Garcia-Romera I, Ocampo J., 2014. Influence of an organic amendment comprising saprophytic and mycorrhizal fungi on soil quality and growth of Eucalyptus globulus in the presence of sewage sludge contaminated with aluminium. Arch. Agron. Soil Sci. 60 (9), 1229-1248.

[24] Insam H, Merschak P., 1997. Nitrogen leaching from forest soil cores after amending organic recycling products and fertilizers. Waste Manage. Res. 15, 277-292. 
International Journal of Advances in Scientific Research and Engineering (ijasre), Vol 6 (4), April -2020

[25] Hue NV, Sobiesczyk BA., 1999. Nutritional values of some biowastes as soil amendments. Compost Sci. Util. 7, 34-41. [26] Springob G, Kirchmann H., 2003. Bulk soil C to N ratio as a simple measure of net N mineralization from stabilized soil organic matter in sandy arable soils. Soil. Biol. Biochem. 35, 629-632.

[27] Mokolobate MS, Haynes RJ., 2002. Comparative liming effect of four organic residues applied to an acid soil. Biol. Fertil. Soils 35, 79-85.

[28] Harter RD., 2002. Acid Soils of the Tropics. ECHO Technical Note.; 8pp. Accessible via http://echonet.org/tropicalag/technotes/Acidsoil.pdf (22 Feb 2020).

[29] Foy CD., 1988. Plant adaptation to acid aluminum-toxic soils. Commun. Soil Sci. Plant Anal. 19, 959-987.

[30] Coscione AR, Andrade JC, van Raij B., 1998. Revisiting titration procedures for the determination of exchangeable acidity and exchangeable aluminumin soils. Commun. Soil Sci. Plant Anal. 29, 1973-1982.

[31] Smith SR., 2009. A critical review of the bioavailability and impacts of heavy metals in municipal solid waste composts compared to sewage sludge. Environ. Int. 35 (1), 142-156.

[32] Brady NC, Weil RR. The Nature and Properties of Soils, 11th Edition. Prentice Hall, Inc, Simon and Shuster Co., New Jersey. 1996.

[33] Iyamuremye F, Dick RP, Baham J., 1996. Organic amendments and phosphorus dynamics: 1. Phosphorus chemistry and sorption. Soil Sci. 161, 426-435.

[34] Naramabuye FX, Haynes RJ, Modi AT., 2008. Cattle manure and grass residues as liming materials in a semi-subsistence farming system. Agri. Ecos. Env. 124, 136-141.

[35] Agegnehu G, Bird M, Nelson P, Bass A., 2015. The ameliorating effects of biochar and compost on soil quality and plant growth on a Ferralsol. Soil Res. 53, 1-12.

[36] Lori M, Symnaczik S, Mäder P, De Deyn G, Gattinger A., 2017. Organic farming enhances soil microbial abundance and activity-a meta-analysis and meta-regression. PLoS One. 12, e0180442.

[37] Shi Y, Ziadi N, Hamel C, Bittman S, Hunt D, Lalande R, Shang J., 2018. Soil microbial biomass, activity, and community composition as affected by dairy manure slurry applications in grassland production. Appl. Soil Ecol. 125, 97-107.

[38] Doan TT, Henry-des-Tureaux T, Rumpel C, Janeau JL, Jouquet P., 2015. Impact of compost, vermicompost and biochar on soil fertility, maize yield and soil erosion in northern Vietnam: a three-year mesocosm experiment. Sci. Total Environ. 514, 147154.

[39] Unc A, Goss MJ., 2004. Transport of bacteria from manure and protection of water resources. Appl. Soil Ecol. 25 , 1-18. [40] Sun R, Zhang XX, Guo X, Wang D, Chu H., 2015. Bacterial diversity in soils subjected to long-term chemical fertilization can be more stably maintained with the addition of livestock manure than wheat straw. Soil Biol. Biochem. 88, 9-18.

[41] Waring BG, Averill C, Hawkes CV., 2013. Differences in fungal and bacterial physiology alter soil carbon and nitrogen cycling: Insights from meta-analysis and theoretical models. Ecology Letters 16:887-94.

[42] Caldwell BA., 2005. Enzyme activities as a component of soil biodiversity: A review. Pedobiologia 49:637-644.

[43] Zhang P, Chen X, Wei T, Yang Z, Jia Z, Yang B, Han Q, Ren X., 2016. Effects of straw incorporation on the soil nutrient contents, enzyme activities, and crop yield in a semiarid region of China. Soil Tillage Res. 160, 65-72.

[44] Dick RP, Breakwell DP, Turco RF., 1996. Soil enzyme activities and biodiversity measurements as integrative microbiological indicators. in J. W. Doran and A. J. Jones, eds. Methods for assessing soil quality. Special publ. no 49. Soil Science Society of America, Madison, WI.; Pp 247-271.

[45] Ding X, Qiao Y, Filley T, Wang H, Lü X, Zhang B, Wang J., 2017. Long-term changes in land use impact the accumulation of microbial residues in the particle-size fractions of a Mollisol. Biol. Fertil. Soils. 53, 281-286.

[46] Erhunmwunse AS, Olayinka A., 2018. Macronutrient-enriched compost increases microbial population, bioavailability of nutrients, and maize (Zea mays 1.) growth in an Ultisol. Nigerian J. Soil Science 28:91-105. 
International Journal of Advances in Scientific Research and Engineering (ijasre), Vol 6 (4), April -2020

[47] Peltoniemi K, Pyrhönen M, Laiho R, Moilanen M, Fritze, H., 2016. Microbial communities after wood ash fertilization in a boreal drained peatland forest. Eur. Journal Soil Biol. 76, 95-102.

[48] Heijboer A, ten Berge HFM, de Ruiter PC, Jørgensen HB, Kowalchuk GA, Bloem J., 2016. Plant biomass, soil microbial community structure and nitrogen cycling under different organic amendment regimes; a 15N tracer-based approach. Appl. Soil Ecol. 107, 251-260. 